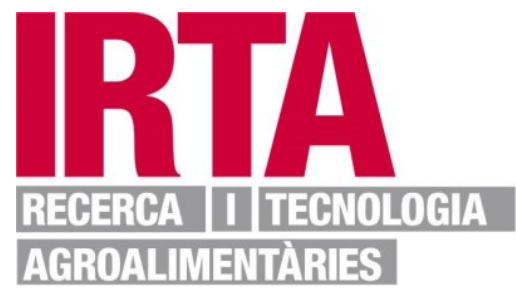

This document is a postprint version of an article published in Food Control (c) Elsevier after peer review. To access the final edited and published work see https://doi.org/10.1016/j.foodcont.2020.107460

Document downloaded from:

IRTA Pubpro

Open dgital archive 


\title{
Physicochemical characterisation of restructured Fenalår and safety implications of salt and nitrite reduction
}

\author{
Coll-Brasas ${ }^{1}$, E., Possas ${ }^{1}$, A., Berg ${ }^{2}$, P., Grabež ${ }^{3}$, V., Egelandsdal ${ }^{3}$, B., Bover-Cid ${ }^{1}$, S. and \\ Fulladosa ${ }^{1}$, E.* $^{*}$ \\ ${ }^{1}$ IRTA, Food Technology and Food Safety Programs, Finca Camps i Armet, E-17121 Monells, Girona, Spain. \\ ${ }^{2}$ Nortura Tynset and Oslo, Meierigata 3, 2500 Tynset and Lorenveien 37, 0513 Oslo, Norway. \\ ${ }^{3}$ Faculty of Chemistry, Biotechnology and Food Science, Norwegian University of Life Sciences, 1430 Ås, \\ Norway.
}

\begin{abstract}
There is a new trend to produce dry-cured ham from lamb in shorter times by boning the ham before salting to later obtain restructured hams that are easier to dry and slice. However, little information about the physicochemical characteristics of Norwegian Fenalårs during the process or the safety implications of their elaboration procedures is reported in the literature. The aim of this study was to characterize the colour, texture and physicochemical properties of restructured Fenalårs when using Standard Salting (SS), Salt Reduced (SR) and a Non-Nitrite Salt Reduced (NNSR) treatments. Microbiological safety implications of the elaboration process when using the different salting treatments were also assessed using predictive microbiology. To do so, sixty Fenalårs were elaborated using a Standard Salting (SS), a Salt reduced (SR) and a Non-Nitrite Salt Reduced (NNSR) treatments. Physicochemical characterization (instrumental colour and texture and Zinc Protoporphyrin content) was performed at the end of the process using thirty Fenalårs. The rest of the Fenalårs were used to characterize the product through the elaboration process $\left(\mathrm{pH}\right.$ and $\mathrm{a}_{\mathrm{w}}$ ) for the evaluation of microbiological hazards when using the different salting treatments using predictive microbiology. Results showed a significant increase in softness when reducing salt content and a decrease of redness when no nitrite was used, attributed to the formation of ZnPP content instead of nitrosylmyoglobin. In terms of risk assessment, the decrease of $a_{\mathrm{w}}$ through the elaboration process reduced the growth capacity of all the microorganisms evaluated. However, microbiological safety implications in salt reduced Fenalårs are important, especially when no nitrite was added, because the considerable increase of growth potential of $L$. monocytogenes. The increase of growth potential of proteolytic $C$. botulinum is very little and no relevant effect of nitrite on growth potential of $S$. aureus was observed.

Predictive microbiology and optimization of the process to enhance $\mathrm{ZnPP}$ formation can help to ensure safety and quality of salt reduced restructured Fenalårs without additives.
\end{abstract}

Key words - Dry-cured ham, lamb, colour, texture, ZnPP, nitrite elimination, salt reduction, predictive microbiology. 


\section{Highlights}

- There is a new trend to reduce salt content and additives in Fenalår.

- Salt content reduction increases softness and microbial hazards.

- No addition of nitrite decreases redness and increases microbial hazards.

- Process optimization can help to improve non-nitrite salt reduced Fenalår quality.

- Predictive microbiology can help to ensure safety of elaboration process.

\section{Introduction}

Fenalår is a traditional Norwegian dry-cured product prepared from lamb or mutton leg. Fenalår fra Norge ("Fenalår from Norway") became a legal Protected Geographical Indication (PGI) in Norway in October 2012 (Håseth, Thorkelsson, Puolanne \& Sidhu, 2014), and a PGI in Europe in 2017 (Regulation (EU) No. 1752/2017). According to the traditional elaboration process, the leg is pile salted with the bone inside. However, there is a new trend to remove the bone before salting to later obtain a restructured Fenalår from different meat pieces which can be elaborated in shorter times and easily sliced and sold as a ready-to-eat product. This restructured Fenalår could be as appreciated by consumers as PGI Fenalår. Although long-dry aged products are well appreciated by consumers (Villalobos-Delgado et al., 2014), other authors found that some consumers preferred dry-cured ham from sheep with short maturation times and cheaper prices (De Andrade et al., 2017).

Restructured elaboration procedures have been previously used to elaborate dry-cured products (Fulladosa, Serra, Gou \& Arnau, 2009; Romero de Ávila, Hoz, Ordóñez \& Cambero, 2014). Production of restructured Fenalår is also of interest to the Norwegian meat industry, but the safety implications and the quality of the final product need to be evaluated. Besides, the tendency to reduce salt content is also becoming more important for Fenalår, which has an above average salt content for dry-cured products, in order to comply with consumers demands and European nutritional recommendations (European Commission, 2020). However, salt content reduction in dry-cured meat products is not straightforward since it can lead to an increase in microbiological safety issues (Inguglia, Zhang, Tiwari, Kerry \& Burgess, 2017; Taormina, 2010) and cause quality defects in the final product (Costa-Corredor, Serra, Arnau \& Gou, 2009). Reduction or elimination of curing additives to comply with clean label requirements is also emerging. However, nitrite is not only used to achieve the typical cured colour in the final product (Cassens, Greaser, Ito \& Lee, 1979; Honikel, 2008), but also for food safety purposes, i.e. to inhibit the growth of Clostridium botulinum (Honikel, 2008). Although dry-cured ham production without curing agents is feasible (Iacumin et al., 2019; Parolari, Aguzzoni \& Toscani, 2016), it must be done with some caution (Buchanan \& Phillips, 1990) especially when using restructured hams and salt reduced treatments in which microbiological contamination is more prone to occur (Fulladosa, Sala, Gou, Garriga \& Arnau, 2012). 
The microbiological safety implications of lowering the amount of salt and nitrite in restructured Fenalår have not been studied before. Listeria monocytogenes and Salmonella spp. are often involved in alerts of the Rapid Alert System for Food and Feed (RASFF) concerning dry-cured meat products. The current legislation establishes microbiological criteria for both hazards in ready-to-eat meats (European Commission, 2005). In addition, E. coli and Salmonella have been described as causative agents of outbreaks associated with the consumption of salted dry-cured meat products (Holck, Axelsson, McLeod, Rode \& Heir, 2017; Omer et al., 2018). Staphylococcus aureus is also a pathogen of concern due to its ubiquitous and versatile character and its role in outbreaks linked to the consumption of dry-cured hams (Rajkovic, 2012; Portocarrero, Newman \& Mikel, 2002). Besides, nitrite removal from meat product formulations could increase the probability of the growth of C. botulinum in these products (Taormina, 2010).

Predictive microbiology models have been applied by food safety authorities in order to evaluate the microbiological safety consequences of changes in food processing and preservation (Messens et al., 2018), including salt reduction in Spanish cured meat products (AESAN, 2011). Predictive models are mathematical tools to estimate microbial behaviour in foods, i.e. growth, transfer, survival or inactivation, as affected by a series of intrinsic and environmental factors, such as $\mathrm{pH}$, aw, nitrite and temperature, without the requirement of time-consuming challenge-tests (Perez-Rodriguez \& Valero, 2013). Robust predictive models accounting for the most relevant factors governing microbial behaviour in dry-cured products have been described and can be applied to evaluate safety implications (Zurera-Cosano et al., 2011).

The effects of salt reduction or the microbiological safety implications of nitrite elimination have been reported in pork cured meat products (Higuero, Moreno, Lavado, Vidal-Aragón \& Cava, 2020), though no systematic studies for different salt levels in Fenalår can be found in the literature. Similarly, several types of pork based dry-cured meat products, such as PDO Parma ham (Laureati et al., 2014), Bayonne ham (Monin et al., 1997) or TEG Serrano ham (Guàrdia, Aguiar, Claret, Arnau \& Guerrero, 2010) have been extensively characterized. Although some studies dealing with dry-cured products from sheep (De Andrade et al., 2017; Teixeira, Fernandes, Pereira, Manuel \& Rodrigues, 2017) and goat (Ivanovic, Nesic, Pisinov \& Pavlovic, 2016) from different countries have been found in the literature, little information regarding the textural and physicochemical characteristics of bone-in or restructured Norwegian Fenalår is reported.

Thus, the aim of our study was to characterize the colour, texture and physicochemical properties of restructured Fenalårs when using Standard Salting (SS), Salt Reduced (SR) and Non-Nitrite Salt Reduced (NNSR) treatments. Microbiological safety implications of the elaboration procedure when using the different salting treatments were also assessed using predictive microbiology. 


\section{Material and methods}

\subsection{Raw material selection and elaboration process of restructured Fenalår}

Sixty Norwegian White lambs fed with coastal grazing were obtained. The animals were 4 months old and from the same production system. All the animals were slaughtered in Førde commercial slaughterhouse over the period of 1 day. After carcass dissection, legs were vacuum packed and stored at $-20{ }^{\circ} \mathrm{C}$ for 7 days. Frozen legs were thawed at $15{ }^{\circ} \mathrm{C}$ (room temperature) for $24 \mathrm{~h}$. The ultimate $\mathrm{pH}$ in Semimembranosus muscle was $5.63 \pm 0.04$ ( $\mathrm{pH}$ meter, Mettler Toledo AG 8603 Schwerzenbach, Switzerland). The legs ( $\mathrm{n}=120)$ were boned, and the connective tissue and subcutaneous fat removed. For restructured Fenalår production, 2 legs were netted (double rubber 110 net, ScotNet, Scotland) and manually rubbed in fine salt. The netted green hams were vacuum packed in shrink bags (polyamide/EVO/polyethylene; oxygen permeability of $12 \mathrm{cc} / \mathrm{m}^{2} / 24 \mathrm{~h}$ at $23{ }^{\circ} \mathrm{C}, 0 \% \mathrm{RH}$ and $1 \mathrm{~atm}$, and a water permeability of $8 \mathrm{~g} / \mathrm{m}^{2} / 24 \mathrm{~h}$ at $38^{\circ} \mathrm{C}, 90 \% \mathrm{RH}$ and $1 \mathrm{~atm}$; Bemis ${ }^{\circledR}$ Company Inc. USA) together with the corresponding amount of salt inside the plastic bags according to the salting treatments described below.

Three different salting treatments were used: Standard Salting (SS) using 4.8g of salt/100g raw meat and $144 \mathrm{ppm}$ nitrite $(\mathrm{n}=24)$; Salt Reduced (SR) using $3.9 \mathrm{~g}$ of salt $/ 100 \mathrm{~g}$ raw meat and 144 ppm nitrite (8\% reduction) $(n=18)$; and Non-Nitrite Salt Reduced (NNSR) using only $3.9 \mathrm{~g}$ of salt $/ 100 \mathrm{~g}$ raw meat $(\mathrm{n}=18)$. The salting step occurred in the cold room at $2-4{ }^{\circ} \mathrm{C}$ for 42 days. After the salting period, Fenalårs were treated with a $4 \%$ potassium-sorbate solution for $1.5 \mathrm{~h}$ at $13{ }^{\circ} \mathrm{C}$ to avoid mould growth and dried at $18{ }^{\circ} \mathrm{C}$ with an $\mathrm{RH}$ of $60 \%$ for $48 \mathrm{~h}$. Later, Fenalårs were dried at $13{ }^{\circ} \mathrm{C}$ and an $\mathrm{RH}$ of $74 \%$ for an additional 10 days. Then, Fenalårs were smoked with friction-smoke from beech wood for 6 hours before being returned to the chamber at $13{ }^{\circ} \mathrm{C}$ for 13 days. Seven days later, the Fenalårs were pressed for 48 hours. Once this was finished, Fenalårs were hung up again at $13{ }^{\circ} \mathrm{C}$ with a relative humidity of $74 \%$ until achieving a weight loss of $36 \%$ (16 days). A schematic representation of the restructured Fenalår elaboration process is shown in Figure 1. During the process, weight loss and temperature were determined twice per week. 


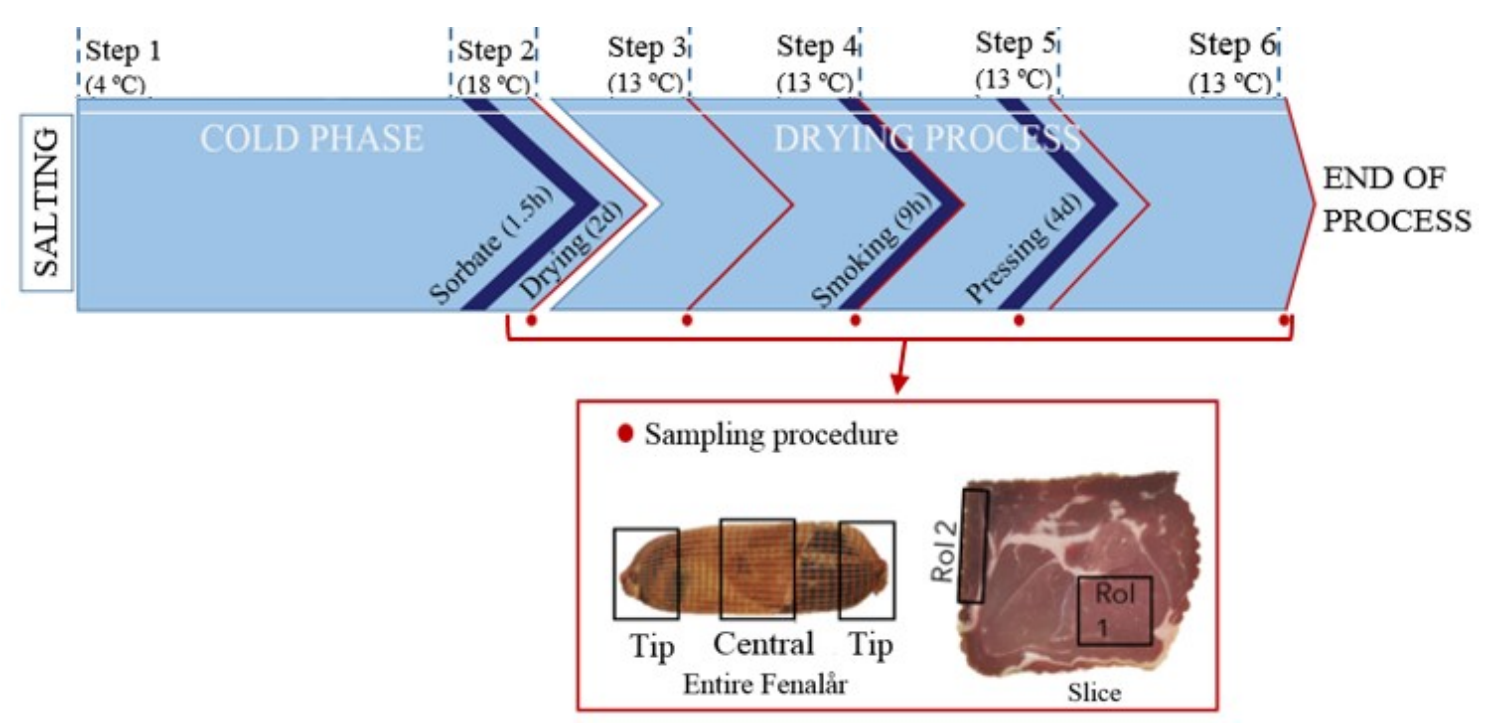

Figure 1. Schematic representation of restructured Fenalår elaboration process and sampling procedure performed at each step: Step 1 (42 days), Step 2 (2 days); Step 3 (10 days), Step 4 (13 days), Step 5 (7 days) and Step 6 (16 days).

\subsection{Sampling procedure}

Thirty restructured Fenalårs elaborated using SS $(n=10)$, SR $(n=10)$ and NNSR $(n=10)$ salting treatments were sampled at the end of the process (when a weight loss of $36 \%$ was reached) (Figure 1). A $5 \mathrm{~cm}$ thick slice was sampled in the central part of the ham and used for instrumental colour determinations. The remaining part of the Fenalår was used for instrumental texture analysis and the determination of salt, water and $\mathrm{Zn}$ protoporphyrin $(\mathrm{ZnPP})$ contents.

To study the microbiological hazards of the restructured Fenalår elaboration procedure, the rest of the Fenalårs $(n=30)$ were sampled at different steps of the manufacturing process (after 44, 54, 67, 74 and 90 days of processing). At each step of the process, a total of 6 Fenalår from different salting treatments (SS, SR and NNSR) (see Table 2) were sampled in two different areas (the central and the tip area), obtaining $10 \mathrm{~cm}$ thick slices in which two or three regions of interest (RoI), depending on the Fenalår, were selected (Figure 1). The $\mathrm{a}_{\mathrm{w}}$ and $\mathrm{pH}$ were measured in all the ROIs $(\mathrm{n}=166)$.

\subsection{Instrumental colour}

A Minolta Spectrophotometer CM 700d colorimeter (Konica Minolta Optics, Inc. Japan) with $2^{\circ}$ standard observer and D65 illuminant was used to measure colour in the CIELAB space (Commission Internationale de l'Eclairage, 1976): lightness (L*), redness (a*) and yellowness $\left(\mathrm{b}^{*}\right)$ on the $5 \mathrm{~cm}$ thick slice. Colour was measured in triplicate.

\subsection{Instrumental texture}

Three or four $2.0 \mathrm{~cm}$ thick slices were obtained from which a minimum of five parallelepipeds were cut with the exact same dimensions $(2 \mathrm{~cm} \times 2 \mathrm{~cm} \times 1.5 \mathrm{~cm})$ from the different muscles available. The identification of the muscle was not possible since it is a 
restructured product. The pieces were wrapped in plastic foil to avoid drying and kept at $4{ }^{\circ} \mathrm{C} \pm 2{ }^{\circ} \mathrm{C}$ for $24 \mathrm{~h}$ for temperature stabilization. A Stress Relaxation test was performed because it allows detection of defective textures (Morales et al., 2007). A Texture Analyser TA - HD plus 6014 (Stable Micro Systems Ltd, Surrey, England) provided with $30 \mathrm{~kg}$ load cell and a $60 \mathrm{~mm}$ diameter compression plate (SMS P/45) was used. Samples were compressed to $25 \%$ of their original height, at a crosshead speed of $5 \mathrm{~mm} / \mathrm{s}$ and at a temperature of $4{ }^{\circ} \mathrm{C} \pm 2{ }^{\circ} \mathrm{C}$. The force decay or relaxation versus time $\mathrm{Y}_{(\mathrm{t})}$ was recorded obtaining a deformation curve and it was calculated as follows:

$$
\mathrm{Y}_{(\mathrm{t})}=\frac{\mathrm{F}_{0}-\mathrm{F}_{(\mathrm{t})}}{\mathrm{F}_{0}}
$$

where $\mathrm{F}_{0}(\mathrm{~kg})$ is the initial force and $\mathrm{F}_{(\mathrm{t})}$ is the force recorded after $\mathrm{t}$ seconds of relaxation. The force decay at $2 \mathrm{~s}\left(\mathrm{Y}_{2}\right)$ and $90 \mathrm{~s}\left(\mathrm{Y}_{90}\right)$ were calculated.

\subsection{Physicochemical analysis}

The $a_{w}$ was measured with an AquaLab ${ }^{\text {TM }}$ instrument (AquaLab Series 3, Decagon devices Inc. Pullman, Washington 99163, USA). Chloride content was determined according to (ISO 1841-2, 1996) using a potentiometric corning 926 chloride Analyzer. Moisture content was determined by drying at $103{ }^{\circ} \mathrm{C} \pm 2{ }^{\circ} \mathrm{C}$ until a constant weight was reached AOAC (1990). All measurements were done in triplicate.

$\mathrm{ZnPP}$ was quantitatively extracted in subdued light conditions with an ethyl acetate/acetic acid/dimethyl sulfoxide solvent mixture $(10: 2: 1, \mathrm{v} / \mathrm{v} / \mathrm{v})$ in quadruplicate as described (Bou, Llauger, Arnau \& Fulladosa, 2018). In brief, 2g of ground sample were weighed into $50 \mathrm{ml}$ capacity centrifuge tubes and homogenized using an UltraTurrax T25 model disperser (IKA Werke GmbH \& Co. KG, Staufen, Germany) for one minute at $9000 \mathrm{rpm}$ with $10 \mathrm{ml}$ of the solvent mixture while the tube was immersed in ice. The sample residues were re-extracted (few second burst) with the same volume of solvent mixture and added to the previous one. After extraction on ice for 20 minutes and centrifugation $(1100 \mathrm{~g}, 14$ min, $4{ }^{\circ} \mathrm{C}$ ), the supernatant was filtered through a filter paper (grade 1) and collected into a volumetric flask. The solvent extractions were performed until the final volume was attained (typically 20ml). Two hundred microliters of extracts were transferred to 96microwell plates and sealed with polyolefin acrylate sealing tape. The samples were then incubated for two minutes at $30{ }^{\circ} \mathrm{C}$ and shaken for 30 seconds before measuring the fluorescence of ZnPP using a Thermo Fisher Scientific Varioskan microplate reader (Waltham, Massachusetts, USA) with the excitation at $416 \mathrm{~nm}$ and the emission at $588 \mathrm{~nm}$. Ethyl acetate/acetic acid/dimethyl sulfoxide solvent mixture $(10: 2: 1, \mathrm{v} / \mathrm{v} / \mathrm{v})$ was used as a blank. Each sample was analysed four times, and the excitation and emission spectra of the standards and samples were compared. ZnPP content was calculated using a calibration curve prepared with ZnPP standard solutions and expressed on the wet weight (ww) basis and dry matter $(\mathrm{dm})$ basis $(\mathrm{ZnPP}$ content $\mathrm{DM}=\mathrm{ZnPP}(\mathrm{mg}) /($ sample $(\mathrm{kg})-$ water $(\mathrm{kg})))$. 


\subsection{Assessment of food safety implications associated with different elaboration treatments}

The behaviour of Listeria monocytogenes, Salmonella, Staphylococcus aureus and Clostridium botulinum non-proteolytic and proteolytic in restructured Fenalår elaborated with different salting treatments was assessed and compared by applying the predictive models available in ComBase Predictor (www.combase.cc). For simulations with the predictive models, worse case scenarios were set by using the highest values of $\mathrm{pH}, \mathrm{a}_{\mathrm{w}}$ and temperature recorded in each step of the restructured Fenalår elaboration process as model inputs (Table 2). Simulations using nitrite concentration of $72 \mathrm{ppm}$ as the input value for the model were performed to consider the uneven diffusion of the added nitrite to the internal parts of Fenalår and the possible transformation to non-active substances such as nitrate (estimation 10-40\%), bound to lipids (1-15\%) or lost as gas $(1-5 \%)$ (Cassens et al., 1979; Honikel, 2008). Kinetic parameters, i.e. growth rate $\left(1 / \mathrm{h}^{-1}\right)$ resulting from the doubling time (h) provided by the predictive tool was estimated for each sampling step of the production process, i.e. after 42, 44, 54, 67, 74 and 90 days of processing. To assess the impact of the elaboration process of restructured Fenalår, the index time increase $\left(t_{i n c}\right)$ was used following the approach of the Spanish Agency for Food Safety (Zurera-Cosano et al., 2011). This index is defined as the time required by the microorganism to increase its concentration a given magnitude, e.g. $1 \log$ unit. The impact of the salt and/or nitrite concentration was assessed in relative terms, e.g. the percentage of reduction of $t_{i n c}$ in the SR and NNSR products with respect to the SS. The antimicrobial effect of sorbate and the phenolic compounds present in the smoke was not evaluated due to the lack of predictive models including these factors. However, since sorbate and smoking were equally applied in all elaboration treatments, it was assumed that their influence on microbial behaviour was similar for SS, SR and NNSR products.

\subsection{Statistical analysis}

A one-way ANOVA was used to evaluate the effect of the salting treatment (SS, SR and NNSR) on chemical, instrumental colour and instrumental texture characteristics. Differences between mean values were tested by means of Tukey's test at $\alpha=0.05$. All the analysis was performed using the statistical package XLSTAT v.2016.3. (Addinsoft SARL, Paris, France). 


\section{Results and discussion}

\subsection{Physicochemical characterization}

Chemical characteristics of restructured Fenalårs are shown in Table 1. Mean salt content of SS Fenalårs was $5.8 \%$, being similar to traditional bone-in Fenalår reported to be $5.42 \%$ by Petrova, Tolstorebrov, Mora, Toldrá \& Eikevik (2016). "Fenalår fra Norge PGI", which comprises the varieties "Traditional" (minimum 30\% desiccation and dry-curing period between three and six months) and "Matured" (minimum 35\% desiccation and a dry-curing period between five and nine months) establish a maximum salt content lower than 9\% and 7\%, respectively (Regulation (EU) No. 1752/2017). However, salt content of Fenalår production can vary greatly, showing values from $5 \%$ to $10 \%$, as reported by Håseth et al. (2014). Other lamb/sheep dry-cured products also show a large variation but lower salt contents (Stojković et al., 2015). Teixeira et al. (2017) reported a salt content of $3.8 \%$ in goat and $4.7 \%$ in sheep cured legs. Ivanovic et al. (2016) found values of $4.5 \%$ in goat smoked ham, whereas Paleari, Moretti, Beretta \& Caprino (2006) reported a salt content of 3.53\% in dry-cured lamb thighbone from Lamon and Bergamasca breeds. In comparison to pork dry-cured ham on the market, both SS and SR restructured Fenalårs showed similar salt content. A market study (http://www.innovacc.cat/wpcontent/uploads/2017/05/Annex_9.2._Informe_final.pdf) showed salt content values of $5.26 \%, 4.81 \%, 5.32 \%$ and $5.40 \%$ for Parma PDO, Alto Addigio PGI, TGE Serrano and Culatello di Zibello PDO, respectively. Tomažin et al. (2020) studied Kraški pršut (Slovenian ham), reporting salt values between $3.61 \%$ and $5.68 \%$. 
Table 1: Mean \pm standard deviation of chemical, instrumental colour and instrumental texture parameters of restructured Fenalår at the end of the process using different salting treatments.

\begin{tabular}{|c|c|c|c|c|c|}
\hline & \multicolumn{3}{|c|}{ Salting treatments } & \multirow[b]{2}{*}{ RMSE } & \multirow[b]{2}{*}{ p-value } \\
\hline & SS & SR & NNSR & & \\
\hline $\mathrm{n}$ & 10 & 10 & 10 & & \\
\hline Weight loss (\%) & $36.4 \pm 0.9$ & $36.7 \pm 0.49$ & $36.5 \pm 0.32$ & 0.43 & 0.543 \\
\hline \multicolumn{6}{|l|}{$\begin{array}{l}\text { Physicochemical } \\
\text { parameters }\end{array}$} \\
\hline $\mathrm{NaCl}(\%)$ & $5.8 \pm 0.4^{\mathrm{a}}$ & $4.9 \pm 0.2^{b}$ & $4.8 \pm 0.3^{\mathrm{b}}$ & 0.30 & 0.001 \\
\hline Moisture (\%) & $56.8 \pm 0.5$ & $56.6 \pm 1.6$ & $57.9 \pm 3.6$ & 2.38 & 0.661 \\
\hline $\mathrm{pH}$ & $5.6 \pm 0.0$ & $5.7 \pm 0.0$ & $5.6 \pm 0.0$ & 0.03 & 0.179 \\
\hline$a_{\mathrm{w}}$ & $0.909 \pm 0.007$ & $0.917 \pm 0.001$ & $0.918 \pm 0.001$ & 0.005 & 0.066 \\
\hline $\mathrm{ZnPP}(\mathrm{mg} / \mathrm{kg}) \mathrm{ww}^{1}$ & $0.03 \pm 0.09^{\mathrm{b}}$ & $0.18 \pm 0.15^{\mathrm{b}}$ & $10.11 \pm 2.9^{\mathrm{a}}$ & 1.752 & $<0.0001$ \\
\hline $\mathrm{ZnPP}(\mathrm{mg} / \mathrm{kg}) \mathrm{dw}^{2}$ & $0.07 \pm 0.16^{\mathrm{b}}$ & $0.42 \pm 0.36^{\mathrm{b}}$ & $23.70 \pm 4.88^{\mathrm{a}}$ & 2.915 & $<0.0001$ \\
\hline \multicolumn{6}{|c|}{ Instrumental colour parameters } \\
\hline $\mathrm{L}^{*}$ & $34.9 \pm 1.9$ & $33.6 \pm 1.0$ & $35.4 \pm 2.0$ & 1.88 & 0.345 \\
\hline$a^{*}$ & $12.2 \pm 1.1^{\mathrm{a}}$ & $12.3 \pm 1.29^{\mathrm{a}}$ & $6.9 \pm 1.3^{\mathrm{b}}$ & 1.42 & 0.000 \\
\hline$b^{*}$ & $4.7 \pm 0.8$ & $4.8 \pm 0.6$ & $4.2 \pm 1.5$ & 1.11 & 0.675 \\
\hline
\end{tabular}

\section{Instrumental texture parameters}

\begin{tabular}{|c|c|c|c|c|c|}
\hline $\mathrm{F}_{0}(\mathrm{~kg})$ & $1.73 \pm 0.43^{\mathrm{a}}$ & $1.18 \pm 0.32^{\mathrm{b}}$ & $1.09 \pm 0.43^{\mathrm{b}}$ & 0.391 & 0.005 \\
\hline $\mathrm{Y}_{2}$ & $0.398 \pm 0.009^{b}$ & $0.426 \pm 0.023^{\mathrm{a}}$ & $0.434 \pm 0.027^{\mathrm{a}}$ & 0.0220 & 0.005 \\
\hline $\mathrm{Y}_{90}$ & $0.708 \pm 0.014^{\mathrm{b}}$ & $0.735 \pm 0.021^{\mathrm{a}}$ & $0.744 \pm 0.026^{\mathrm{a}}$ & 0.0210 & 0.004 \\
\hline
\end{tabular}

${ }^{a b}$ Means within rows with a different letter are significantly different $(p \leq 0.05)$. SS: Standard Salting; SR: Salt Reduced; NNSR: Non-Nitrite Salt Reduced. RMSE: root mean square error of the linear model. ${ }^{1}$ Expressed on a wet weight basis; ${ }^{2}$ Expressed on a dry weight basis.

In this study, SR treatment produced a significant decrease of salt content in the final product ( $p \leq 0.05$ ). However, the achieved reduction was only $\sim 15 \%$ and therefore the product could not be labelled as a salt reduced product (Official Journal of the European Communities C 371 01.12.1998). Further reduction of the salt in restructured Fenalår production would require additional investigation of product safety. All the salting treatments, SS and SR/NNSR restructured Fenalårs showed $\mathrm{a}_{\mathrm{w}}$ lower than 0.90 in the final product, according to the general rule of Fenalår fra Norge stablished in the Regulation (EU) No. 1752/2017. However, variation of $\mathrm{pH}, \mathrm{a}_{\mathrm{w}}$ and temperature during the elaboration process should be evaluated to study the microbiological safety implications of the salt reduced treatments. Figure 2 shows fluctuations of $\mathrm{pH}$ and $\mathrm{a}_{\mathrm{w}}$ during the restructured Fenalår elaboration process. 

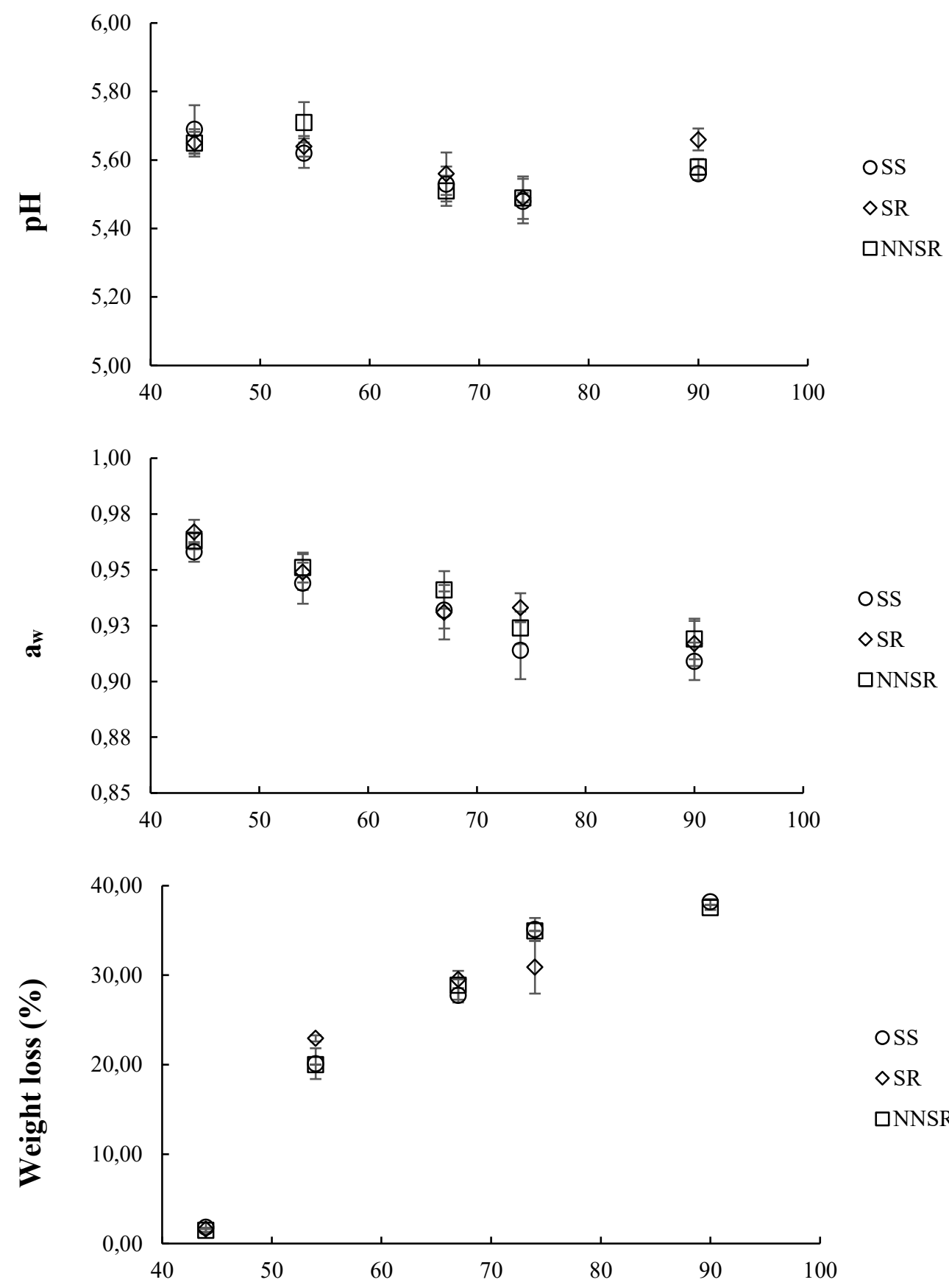

Time (days)

Figure 2. Evolution of $\mathrm{pH}$, water activity $\left(\mathrm{a}_{\mathrm{w}}\right)$ and weight loss through the restructured Fenalår elaboration process using different salting treatments. (o) SS: Standard Salting; $(\diamond)$ SR: Salt Reduced; ( $\square)$ NNSR: Non-Nitrite Salt Reduced. 


\subsection{Characterization of colour and texture}

Colour measurements showed no significant changes between SS and SR treatments for any of the studied parameters ( $\mathrm{L}^{*}, \mathrm{a}^{*}$ and $\mathrm{b}^{*}$ values). In contrast, no addition of nitrite (NNSR) produced a significant decrease of redness ( $a^{*}$ values $)(p \leq 0.05)$. In the case of NNSR, nitrosylmyoglobin is not formed because nitrite has been omitted in the elaboration process. The obtained red colour was in part attributed to ZnPP (Table 1), although other porphyrins such as metmyoglobin could also be present. Given that ZnPP is quite similar to NO-heme, the presence of oxidized forms of myoglobin may contribute to reduced redness values. Wakamatsu, Okui, Ikeda, Nishimura \& Hattori (2004) proved in pork meat that when no nitrites are used, Zn-protoporphyrin (ZnPP) is formed instead of nitrosylmyoglobin, decreasing the redness intensity. To our knowledge, this is the first time that ZnPP formation is reported in lamb dry-cured ham.

Mean ZnPP content in the studied NNSR Fenalår was $23.70 \mathrm{mg} / \mathrm{kg}$ on a dry weight basis (Table 1), whereas it was negligible when using nitrite (SS and SR) because of the inhibition that nitric oxide produces on ZnPP formation (Wakamatsu, Hayashi, Nishimura \& Hattori, 2010). Variations found within Fenalårs from the same group (contents between 19 and $31 \mathrm{mg} / \mathrm{kg} \mathrm{ZnPP} \mathrm{dw}$ ) can be due to the effect of raw ham $\mathrm{pH}$ or salt content variations which have been reported to influence $\mathrm{ZnPP}$ formation (Bou, Llauger, Arnau, Olmos \& Fulladosa, 2020; Wakamatsu et al., 2019). Higher concentrations of ZnPP were reported for non-nitrified Parma dry-cured ham $(43.8 \pm 14 \mathrm{mg} / \mathrm{kg}$ on a dw basis) (Bou et al., 2018) and also for Spanish dry-cured ham elaborated without additives (between $67 \pm 24$ and $95 \pm 11 \mathrm{mg} / \mathrm{kg}$ on a dw basis) (Bou et al., 2020). Wakamatsu, Odagiri, Nishimura, and Hattori (2009) reported ZnPP contents that ranged between 27 and $47 \mathrm{mg} / \mathrm{kg}$ on a wet weight basis in three different muscles (Semimembranosus, Semitendinosus and Biceps femoris) of Parma ham. However, Ghadiri Khozroughi, Kroh, Schlüter \& Rawel (2018) mentioned that red meat (lamb and beef) yielded up to four times higher ZnPP concentrations compared to porcine meat muscle, while there was almost no ZnPP quantified in poultry samples. De Maere et al. (2017) also reported differences of $\mathrm{ZnPP}$ formation in different in vitro meat sources, showing a higher ZnPP formation rate in lamb. However, in this study, this higher formation rate in lamb has not been observed. Lower ZnPP concentration found in lamb Fenalår could be related to the shorter maturation period (4 months) in comparison to the Parma and Spanish dry-cured hams (12-24 months), since processing time is a crucial factor for $\mathrm{ZnPP}$ formation (De Maere et al., 2017). These results suggest that redness of NNSR Fenalår could be improved by optimizing elaboration procedures, i.e. increasing ageing times and/or processing temperatures at the different steps of the process or by selecting raw material with characteristics that enhance formation of ZnPP. It must be remarked that elaboration with or without the bone can also produce important differences on a* values. CollBrasas, Kåsin et al. (2019) reported that traditional bone-in Fenalår with standard salting treatment had significantly $(\mathrm{p} \leq 0.05)$ lower redness values $\left(\mathrm{a}^{*}=7.41\right)$ than restructured Fenalårs analysed in this study $\left(\mathrm{a}^{*}=12.2\right)$. This fact could be explained by the easier diffusion of curing agents inside the product because of the higher nitrified surface of restructured Fenalårs. 
In terms of texture, salt reduction decreased $F_{0}$ and increased force decay at $2\left(\mathrm{Y}_{2}\right)$ and 90 seconds ( $Y_{90}$ ) (Table 2). These results are in agreement with other studies carried out in pork dry-cured ham. Ruiz-Ramírez, Arnau, Serra \& Gou (2005) found that dry-cured ham muscles from pork with lower $\mathrm{NaCl}$ content showed lower hardness, cohesiveness and springiness. Benedini et al. (2012) found an increase of $Y_{2}$ and $Y_{90}$ in low salt class dry-cured ham. Morales, Serra, Guerrero \& Gou (2007) also found that BF muscles from pork dry-cured ham with levels of $\mathrm{NaCl}$ lower than $2 \%$ were more prone to show soft textures. Optimization of the Fenalår elaboration process and corrective actions using emerging technologies (Coll-Brasas, Arnau et al., 2019; Contreras et al., 2020) could help to yield SR and NNSR Fenalårs with similar textural characteristics to SS Fenalårs. 
Table 2: Results of the simulations applying predictive models in order to evaluate the implications of different Fenalår salting treatments on the behaviour of Listeria monocytogenes.

\begin{tabular}{|c|c|c|c|c|c|c|c|c|c|}
\hline $\begin{array}{l}\text { Step of the } \\
\text { process }\end{array}$ & $\begin{array}{c}\text { Temperature } \\
\left({ }^{\circ} \mathbf{C}\right)^{*}\end{array}$ & $\begin{array}{l}\text { Duration } \\
\text { (days) }\end{array}$ & Type & $\begin{array}{c}\text { Maximum } \\
\text { aw }_{w}\end{array}$ & $\begin{array}{c}\text { Maximum } \\
\text { pH }\end{array}$ & $\begin{array}{l}\text { Growth } \\
\text { rate }\left(h^{-1}\right)\end{array}$ & $\begin{array}{l}\text { Doubling } \\
\text { time }(h)\end{array}$ & $\begin{array}{l}\text { Time for } 1 \text { log } \\
\text { increase }(d)\end{array}$ & $\begin{array}{c}\text { Reduction in } \\
\text { comparison to SS }(\%)\end{array}$ \\
\hline \multirow{3}{*}{ Cold phase } & \multirow{3}{*}{4} & \multirow{3}{*}{42} & $\mathrm{SS}$ & 0.959 & 5.70 & 0.004 & 71.25 & 10.4 & 0 \\
\hline & & & SR & 0.969 & 5.67 & 0.005 & 54.98 & 8.3 & 20 \\
\hline & & & NNSR & 0.965 & 5.66 & 0.007 & 44.19 & 6.0 & 43 \\
\hline \multirow{3}{*}{ Drying } & \multirow{3}{*}{18} & \multirow{3}{*}{2} & SS & 0.957 & 5.69 & 0.042 & 7.22 & 1.0 & 0 \\
\hline & & & SR & 0.964 & 5.64 & 0.046 & 6.57 & 0.9 & 9 \\
\hline & & & NNSR & 0.962 & 5.63 & 0.061 & 4.90 & 0.7 & 31 \\
\hline \multirow{3}{*}{ Storage } & \multirow{3}{*}{13} & \multirow{3}{*}{10} & $\mathrm{SS}$ & 0.956 & 5.68 & 0.020 & 14.77 & 2.1 & 0 \\
\hline & & & $\mathrm{SR}$ & 0.960 & 5.68 & 0.023 & 13.24 & 1.8 & 13 \\
\hline & & & NNSR & 0.962 & 5.82 & 0.035 & 8.52 & 1.2 & 43 \\
\hline \multirow{3}{*}{$\begin{array}{l}\text { Smoking and } \\
\text { storage }\end{array}$} & \multirow{3}{*}{13} & \multirow{3}{*}{13} & $\mathrm{SS}$ & 0.943 & 5.62 & 0.013 & 23.49 & 3.2 & 0 \\
\hline & & & SR & 0.943 & 5.61 & 0.013 & 43.49 & 3.2 & 0 \\
\hline & & & NNSR & 0.951 & 5.57 & 0.023 & 13.27 & 1.8 & 43 \\
\hline \multirow{3}{*}{$\begin{array}{l}\text { Pressing and } \\
\text { storage }\end{array}$} & \multirow{3}{*}{13} & \multirow{3}{*}{7} & $\mathrm{SS}$ & 0.932 & 5.63 & 0.009 & 32.70 & 4.6 & 0 \\
\hline & & & SR & 0.943 & 5.63 & 0.013 & 23.49 & 3.2 & 31 \\
\hline & & & NNSR & 0.933 & 5.50 & 0.012 & 24.56 & 3.5 & 25 \\
\hline \multirow{3}{*}{ Final process } & \multirow{3}{*}{13} & \multirow{3}{*}{16} & SS & 0.918 & 5.61 & 0.000 & 0.000 & - & - \\
\hline & & & $\mathrm{SR}$ & 0.927 & 5.69 & 0.009 & 34.80 & 4.6 & - \\
\hline & & & NNSR & 0.928 & 5.63 & 0.011 & 26.53 & 3.8 & - \\
\hline
\end{tabular}

SS: Standard Salting; SR: Salt Reduced; NNSR: Non-Nitrite Salt Reduced.

${ }^{*}$ Temperature of the air of the drying room where the hams were stored. It is assumed as a worst-case overestimate (in general representative of the surface of the product) as a lower temperature could be expected in the product in most of the steps. 


\subsection{Microbial safety implications associated with the different restructured Fenalår salting treatments}

The results of the simulations using predictive models indicated that microbial behaviour in restructured Fenalår varies according to the microorganism and the physicochemical characteristics of the products, which are dependent on the salting treatments used (SS, SR and NNSR) and the temperatures at which each manufacturing step is carried out.

During the cold phase, most of the microbiological hazards evaluated would not be able to grow in Fenalår, either because the temperature was below the minimum growth temperature, i.e. Salmonella, S. aureus, E. coli and proteolytic C. botulinum, and/or due to the presence of nitrites (e.g. non-proteolytic C. botulinum). At this step, among the microorganisms assessed only L. monocytogenes would be able to grow in Fenalår in agreement with its psychrotrophic nature. The $t_{i n c}$ of $L$. monocytogenes in SR and NNSR would be affected in comparison with the value of this index in SS (Table 2). The $t_{i n c}$ of L. monocytogenes in NNSR products would be $43 \%$ lower in comparison with the SS product with $72 \mathrm{ppm}$ of active nitrite. This could be attributed to the fact that salt reduction would yield products with physicochemical characteristics that are slightly different in comparison with the SS product, e.g. a higher maximum $\mathrm{a}_{\mathrm{w}}$ (Table 2). These differences determine changes in the L. monocytogenes growth rate. It was previously reported that under certain circumstances, such as refrigerated storage, nitrite is effective to control $L$. monocytogenes (EFSA, 2003; Tompkin, 2005). The reduction of added nitrite from 144 ppm to $0 \mathrm{ppm}$ in the present study results in products with more favourable conditions for L. monocytogenes growth.

Similarly, during drying at $18{ }^{\circ} \mathrm{C}$ for 2 days, the salt reduction would result in products with a maximum $\mathrm{a}_{\mathrm{w}}$ slightly higher in comparison with SS (Table 2). The $t_{\text {inc }}$ for $L$. monocytogenes would be 31\% and 9\% lower in NNSR and SR products respectively in comparison with SS products, with $72 \mathrm{ppm}$ of active nitrite. Regarding Salmonella and E. coli, assuming that the inhibitory mechanism of nitrites differs among different species and that it is not considered effective to control Gram-negative bacteria such as these pathogens (EFSA, 2017), the reduction of nitrite would not have a relevant effect on the $t_{i n c}$ for NNSR and SR products with respect to SS.

The $t_{\text {inc }}$ of $S$. aureus would increase from $12 \mathrm{~h}$ during the drying step at $18{ }^{\circ} \mathrm{C}$ to $30-63 \mathrm{~h}$ during the subsequent manufacturing steps carried out at $13{ }^{\circ} \mathrm{C}$ in NNSR products, evidencing the positive correlation between temperature and growth rate. Research on the effects of nitrite removal on the behaviour of $S$. aureus in dry-cured products similar to restructured Fenalår are scarce, but research has demonstrated that nitrite failed to control $S$. aureus growth during the production process of a dry-sausage (Bang, Hanson \& Drake, 2008; Gonzales-Barron et al., 2015). It could also grow in medium-salted bacon, independent of the concentration of nitrite or ascorbate (Crowther, Holbrook, BairdParker \& Austin, 1976; Tompkin, 2005). Furthermore, the addition of increasing salt up to $3.64 \%(\mathrm{w} / \mathrm{w})$ and nitrite at $154 \mathrm{ppm}$ did not affect the growth capacity of $S$. aureus during drying of a pork sausage (Bang et al., 2008). Therefore, based on the available scientific information, the $t_{i n c}$ for $S$. aureus in SS, SR and NNSR products would be 
equivalent, i.e. independent of the salt and nitrite concentrations used in the assessed products.

In general, the decrease of $\mathrm{a}_{\mathrm{w}}$ during the steps at $13{ }^{\circ} \mathrm{C}$ would drastically reduce the growth capacity of all the microorganisms evaluated. Model simulations indicated that slight differences in $t_{i n c}$ of L. monocytogenes in SS and SR products would be marked, since the slight differences in the physicochemical parameters of SS and SR Fenalår do not determine changes in growth rate, except after the pressing and storage step (Table 2). Clostridium botulinum non-proteolytic would not be able to grow in products in any of the steps of the manufacturing production process, as the minimum $\mathrm{a}_{\mathrm{w}}$ enabling its growth is 0.97 (ICMSF, 1996), while during drying at $18{ }^{\circ} \mathrm{C}$, proteolytic C. botulinum would not reach 1 log increase in Fenalår $\left(t_{i n c}=14 \mathrm{~d}\right)$ for longer than the actual duration of the drying step. Merialdi et al., (2016) detected a slight growth of 2-2.5 Log units of proteolytic $C$. botulinum in 2 out of 9 samples after 7 days of drying of Parma ham (dry ham without nitrite and nitrate) at $20^{\circ} \mathrm{C}$, though the toxin formation was not evidenced until 14 days.

The reduction of nitrite in the Fenalår elaboration is not a determining factor limiting the growth of Salmonella, E. coli and $S$. aureus, it increases very little the growth potential of proteolytic $C$. botulinum but considerable increases the growth potential of $L$. monocytogenes, consequently the implementation of complementary antimicrobial hurdles (including a decrease of temperature during the process) would be needed in order to assure the microbiological safety of nitrite-reduced products.

It is worth mentioning that the simulations with the ComBase model, which was developed in growth media, usually provide fail-safe predictions, overestimating the growth that would actually occur in real food matrices. Despite the limitations, the tool provides useful simulations to calculate the $t_{i n c}$ for comparing the relative impact of different scenarios (SS, SR and NNSR) of input data.

\section{Conclusions}

Salt reduced restructured Fenalår is challenging to produce since soft textures, important changes in colour and safety hazards during the elaboration process can occur, especially in non-nitrite salting treatments. The elaboration of Fenalår without nitrite must be cautious as it can increase the growth potential of L. monocytogenes and slightly that of proteolytic $C$. botulinum. However, predictive microbiology and the optimization of the process to enhance $\mathrm{ZnPP}$ formation can help to ensure the safety and quality of salt reduced restructured Fenalårs without additives.

\section{Acknowledgements}

This work was supported by the CERCA Programme/Generalitat de Catalunya,), Nortura SA (Norway) and Foods of Norway, Center for Research-based Innovation (Research Council of Norway; grant 237841). Elena Coll Brasas is the recipient of a doctoral fellowship awarded by INIA (Spanish Government, CPD2015-0054, FPI2015-0023). The authors would also acknowledge the contribution of Karoline Kåsin, Lene Ruud, Trond Livden and Anne Mette Grøtli. 


\section{CRediT authorship contribution statement}

E. Coll-Brasas: Investigation, Formal analysis, Writing - original draft, Visualization. A. Possas: Data curation, Writing - original draft, Formal analysis. P. Berg: Supervision, Funding acquisition. V. Grabež: Project administration, Writing - review \& editing, Resources. B. Egelandsdal: Project administration, Supervision, Writing - review \& editing, Resources. S. Bover-Cid: Visualization, Supervision, Writing - review \& editing, Data curation, Formal analysis. E. Fulladosa: Visualization, Supervision, Writing review \& editing, Formal analysis.

\section{References}

AESAN (2010) Report of the Scientific Committee of the Spanish Agency for Food Safety and Nutrition (AESAN) in relation to the effect of salt reduction on the microbiological safety of cured meat products. Revista del Comité Científico de la $\operatorname{AESAN(13),~59-88~}$

AOAC (1990). Official method 950.46, Moisture in meat, B. Air drying. In K. Helrich (Ed.) $\left(15^{\text {th }}\right.$ ed.). Official methods of analysis of the association of official analytical chemists (Vol. II, pp. 931), (1990).

Bang, W., Hanson, D. \& Drake, M. (2008). Effect of salt and sodium nitrite on growth and enterotoxin production of Staphylococcus aureus during the production of airdried fresh pork sausage. Journal of Food Protection, 71(1), 191-195.

Benedini, R., Parolari, G., Toscani, T. \& Virgili, R. (2012). Sensory and texture properties of Italian typical dry-cured hams as related to maturation time and salt content. Meat Science, 90, 431-437.

Bou, R., Llauger, M., Arnau, Olmos, A. \& Fulladosa, E. (2020). Effects of post mortem $\mathrm{pH}$ and salting time on Zinc-protoporphyrin content in nitrite-free Serrano drycured hams. Food Research International, 109156.

Bou, R., Llauger, M., Arnau \& Fulladosa, E. (2018). Zinc-protoporphyrin content in commercial Parma hams is affected by proteolysis index and marbling. Meat Science, 139, 192-200.

Buchanan, R. L. \& Phillips, J. G. (1990). Response Surface Model for Predicting the Effects of Temperature $\mathrm{pH}$, Sodium Chloride Content, Sodium Nitrite Concentration and Atmosphere on the Growth of Listeria monocytogenes. Journal of Food Protection, 53(5), 370-376.

Cassens, R. G., Greaser, M. L., Ito, T. \& Lee, M. (1979). Reactions of nitrite in meat. Food Technology, 33, 46-57.

Coll-Brasas, E., Arnau, Gou, P., Lorenzo Rodriguez, J. M., Garcia-Perez, J. V. \& Fulladosa, E. (2019). Effect of high pressure processing temperature on dry-cured hams with different textural characteristics. Meat Science, 152.

Coll-Brasas, E., Kåsin, K., Grabež, V., Fulladosa, E., Livden, T., Berg, P., Håseth, T. T. \& Egelandsdal, B. (2019). Comparison of colour and texture between Traditional bone-in and Boned fenalår. Paper presented at the $65^{\text {th }}$ International Congress of Meat Science and Technology, Potsdam, Germany.

Commission Internationale de l'Eclairage. (1976). Colorimetry. Publication No. 15, Bureau Central de la CIE, Vienna, Austria. 
Contreras, M., Benedito, J., Quiles, A., Lorenzo, J. M., Fulladosa, E. \& Garcia-Perez, J. V. (2020). Correction of defective textures in packaged dry-cured pork ham by applying conventional and ultrasonically-assisted mild thermal treatments. $L W T$, 109283.

Costa-Corredor, A., Serra, X., Arnau \& Gou, P. (2009). Reduction of $\mathrm{NaCl}$ content in restructured dry-cured hams: Post-resting temperature and drying level effects on physicochemical and sensory parameters. Meat Science, 83(3), 390-397.

Crowther, J., Holbrook, R., Baird-Parker, A. \& Austin, B. (1976). Role of nitrite and ascorbate in the microbiological safety of vacuum packed sliced bacon. Paper presented at the Proceedings of the $2^{\text {nd }}$ International Symposium on Nitrite in Meat Products, Pudoc, Wageningen.

De Andrade, J. C., Nalério, E. S., Giongo, C., de Barcellos, M. D., Ares, G. \& Deliza, R. (2017). Consumer perception of dry-cured sheep meat products: Influence of process parameters under different evoked contexts. Meat Science, 130, 30-37.

De Maere, H., Chollet, S., Claeys, E., Michiels, C., Govaert, M., De Mey, E., Paelinck, H. \& Fraeye, I. (2017). In vitro zinc protoporphyrin IX formation in different meat sources related to potentially important intrinsic parameters. Food and bioprocess technology, 10(1), 131-142.

EFSA (2003). Opinion of the Scientific Panel on biological hazards (BIOHAZ) on the effects of Nitrites/Nitrates on the Microbiological Safety of Meat Products. The EFSA Journal, 14, 1-31.

EFSA (2017). Re-evaluation of potassium nitrite (E 249) and sodium nitrite (E 250) as food additives. The EFSA Journal, 15(6), 1-157.

European Commission (2005). Commission Regulation (EC) No. 2073/2005 of 15 November 2005 on microbiological criteria for foodstuffs. Official Journal European Communitites, 338, 1-26.

European Commission (2020). Summary of Food-Based Dietary Guidelines recommendations for salt for the EU, Iceland, Norway, Switzerland and the United Kingdom. The European Commission's science and knowledge service.

Fulladosa, E., Sala, X., Gou, P., Garriga, M. \& Arnau (2012). K-lactate and high pressure effects on the safety and quality of restructured hams. Meat Science, 91(1), 56-61.

Fulladosa, E., Serra, X., Gou, P. \& Arnau. (2009). Effects of potassium lactate and high pressure on transglutaminase restructured dry-cured hams with reduced salt content. Meat Science, 82(2), 213-218.

Ghadiri Khozroughi, A., Kroh, L. W., Schlüter, O. \& Rawel, H. (2018). Assessment of the bacterial impact on the post-mortem formation of zinc protoporphyrin IX in pork meat. Food Chemistry, 256, 25-30.

Gonzales-Barron, U., Cadavez, V., Pereira, A. P., Gomes, A., Araújo, J. P., Saavedra, M. J., Estevinho, L., Butler, F., Pires, P. \& Dias, T. (2015). Relating physicochemical and microbiological safety indicators during processing of linguiça, a Portuguese traditional dry-fermented sausage. Food Research International, 78, 50-61.

Guàrdia, M. D., Aguiar, A. P. S., Claret, A., Arnau \& Guerrero, L. (2010). Sensory characterization of dry-cured ham using free-choice profiling. Food Quality and Preference, 21(1), 148-155. 
Håseth, T. T., Thorkelsson, G., Puolanne, E. \& Sidhu, M. S. (2014). Nordic products. In F. Toldrá, Y. H. Hui, I. Astiasaran, J. Sebranek \& R. Talon (Eds.), Handbook of fermented meat and poultry ( $2^{\text {nd }}$ ed., pp. 371-376): John Wiley \& Sons.

Higuero, N., Moreno, I., Lavado, G., Vidal-Aragón, M. C. \& Cava, R. (2020). Reduction of nitrate and nitrite in Iberian dry cured loins and its effects during drying process. Meat Science, 163, 108062.

Holck, A., Axelsson, L., McLeod, A., Rode, T. M. \& Heir, E. (2017). Health and safety considerations of fermented sausages. Journal of Food Quality, 2017. Article ID 9753894.25 pages.

Honikel, K.-O. (2008). The use and control of nitrate and nitrite for the processing of meat products. Meat Science, 78(1-2), 68-76.

Iacumin, L., Cattaneo, P., Zuccolo, C., Galanetto, S., Acquafredda, A. \& Comi, G. (2019). Natural levels of nitrites and nitrates in San Daniele dry cured ham PDO, and in meat, salt and sugar used for its production. Food Control, 100, 257-261.

ICMSF (1996). Clostridium botulinum. In T. A. Roberts, A. C. Baird Parker \& R. B. Tompkin (Eds.), Microorganisms in Foods 5: Characteristics of Microbial Pathogens ( $1^{\text {st }}$ ed., pp. 66-111).

Inguglia, E. S., Zhang, Z., Tiwari, B. K., Kerry, J. P. \& Burgess, C. M. (2017). Salt reduction strategies in processed meat products - A review. Trends in Food Science \& Technology, 59, 70-78.

ISO 1841-2 (1996). Meat and meat products. Determination of chloride content - Part 2: Potentiometric method (Reference method). Geneva: International Organization for Standardization.

Ivanovic, S., Nesic, K., Pisinov, B. \& Pavlovic, I. (2016). The impact of diet on the quality of fresh meat and smoked ham in goat. Small Ruminant Research, 138, 53-59.

Laureati, M., Buratti, S., Giovanelli, G., Corazzin, M., Lo Fiego, D. P. \& Pagliarini, E. (2014). Characterization and differentiation of Italian Parma, San Daniele and Toscano dry-cured hams: A multi-disciplinary approach. Meat Science, 96(1), 288-294.

Merialdi, G., Ramini, M., Parolari, G., Barbuti, S., Frustoli, MA., Taddei, R., Pongolini, S., Ardigo, P. and Cozzolin, P. (2016). Study on potential Clostridium botulinum growth and toxin production in Parma ham. Italian Journal of Food Safety, 5:5564

Messens, W., Hempen, M. and Koutsoumanis, K. (2018). Use of predictive modelling in recent work of the Panel on Biological Hazards of the European Food Safety Authority. Microbial Risk Analysis, 10, 37-43

Monin, G., Marinova, P., Talmant, A., Martin, J. F., Cornet, M., Lanore, D. \& Grasso, F. (1997). Chemical and structural changes in dry-cured hams (bayonne hams) during processing and effects of the dehairing technique. Meat Science, 47(1/2), $29-47$.

Morales, R., Serra, X., Guerrero, L. \& Gou, P. (2007). Softness in dry-cured porcine biceps femoris muscles in relation to meat quality characteristics and processing conditions. Meat Science, 77, 662-669. 
Official Journal of the European Communities C 371 01.12.1998. Publication of an application for registration pursuant to the second subparagraph of Article 8(1) of Regulation (EEC) No. 2082/92 on certificates of specific character.

Omer, M. K., Alvarez-Ordonez, A., Prieto, M., Skjerve, E., Asehun, T. \& Alvseike, O. A. (2018). A systematic review of bacterial foodborne outbreaks related to red meat and meat products. Foodborne pathogens and disease, 15(10), 598-611.

Paleari, M. A., Moretti, V. M., Beretta, G. \& Caprino, F. (2006). Characterization of a lamb ham: Fatty acids and volatile compounds composition. Journal of Muscle Foods, 17(4), 398-412.

Parolari, G., Aguzzoni, A. \& Toscani, T. (2016). Effects of processing temperature on color properties of dry-cured hams made without nitrite. Foods, 5(2), 33.

Perez-Rodriguez, F. \& Valero, A. (2013). Predictive microbiology in foods Predictive microbiology in foods (pp. 1-10): Springer.

Petrova, I., Tolstorebrov, I., Mora, L., Toldrá, F. \& Eikevik, T. M. (2016). Evolution of proteolytic and physico-chemical characteristics of Norwegian dry-cured ham during its processing. Meat Science, 121, 243-249.

Portocarrero, S. M., Newman, M., \& Mikel, B. (2002). Staphylococcus aureus survival, staphylococcal enterotoxin production and shelf stability of country-cured hams manufactured under different processing procedures. Meat Science, 62 (2), 267273.

Rajkovic, A. (2012). Incidence, growth and enterotoxin production of Staphylococcus aureus in insufficiently dried traditional beef ham "govedja pršuta" under different storage conditions. Food Control, 27 (2), 369-373.

Regulation (EU) No. 1752/2017. on the Protected Designation of Origin and Protected Geographical Indications established by Article 11 of Regulation (EU) No. 1151/2012. Official Journal of the European Union, 246, 1-29.

Romero de Ávila, M. D., Hoz, L., Ordóñez, J. A. \& Cambero, M. I. (2014). Dry-cured ham restructured with fibrin. Food Chemistry, 159, 519-528.

Ruiz-Ramírez, J., Arnau, Serra, X. \& Gou, P. (2005). Relationship between water content, $\mathrm{NaCl}$ content, $\mathrm{pH}$ and texture parameters in dry-cured muscles. Meat Science, 70, 579-587.

Stojković, S., Grabež, V., Bjelanović, M., Mandić, S., Vučić, G., Martinović, A., Håseth, T. T., Velemir, A. \& Egelandsdal, B. (2015). Production process and quality of two different dry-cured sheep hams from Western Balkan countries. LWT - Food Science and Technology, 64(2), 1217-1224.

Taormina, P. J. (2010). Implications of Salt and Sodium Reduction on Microbial Food Safety. Critical Reviews in Food Science and Nutrition, 50(3), 209-227.

Teixeira, A., Fernandes, A., Pereira, E., Manuel, A. \& Rodrigues, S. (2017). Effect of salting and ripening on the physicochemical and sensory quality of goat and sheep cured legs. Meat Science, 134, 163-169.

Tomažin, U., Škrlep, M., Prevolnik Povše, M., Batorek Lukač, N., Karolyi, D., Červek, M. \& Čandek-Potokar, M. (2020). The effect of salting time and sex on chemical and textural properties of dry cured ham. Meat Science, 161, 107990. 
Tompkin, R. B. (2005). Nitrite. In P. M. Davidson, J. N. Sofos \& A. L. Branen (Eds.), Antimicrobials in food ( $3^{\text {rd }}$ ed.). New York: Marcel Dekker Inc.

Villalobos-Delgado, L. H., Caro, I., Blanco, C., Morán, L., Prieto, N., Bodas, R., Giráldez, F. J. \& Mateo, J. (2014). Quality characteristics of a dry-cured lamb leg as affected by tumbling after dry-salting and processing time. Meat Science, 97(1), 115-122.

Wakamatsu, J., Akter, M., Honma, F., Hayakawa, T., Kumura, H. \& Nishimura, T. (2019). Optimal $\mathrm{pH}$ of zinc protoporphyrin IX formation in porcine muscles: Effects of muscle fiber type and myoglobin content. LWT, 101, 599-606.

Wakamatsu, J., Hayashi, N., Nishimura, T. \& Hattori, A. (2010). Nitric oxide inhibits the formation of zinc protoporphyrin IX and protoporphyrin IX. Meat Science, 84(1), $125-128$.

Wakamatsu, J., Odagiri, H., Nishimura, T. \& Hattori, A. (2009). Quantitative determination of $\mathrm{Zn}$ protoporphyrin IX, heme and protoporphyrin IX in Parma ham by HPLC. Meat Science, 82(1), 139-142.

Wakamatsu, J., Okui, J., Ikeda, Y., Nishimura, T. \& Hattori, A. (2004). Establishment of a model experiment system to elucidate the mechanism by which $\mathrm{Zn}-$ protoporphyrin IX is formed in nitrite-free dry-cured ham. Meat Science, 68(2), 313-317.

Zurera-Cosano, G., Carballeira, A. O., Carrasco, E., Rodríguez, F. P. \& Díaz, A. V. (2011). Informe del Comité Científico de la Agencia Española de Segurida Alimentaria y Nutrición (AESAN) en relación al efecto de la reducción de la sal en la seguridad microbiológica de los productos cárnicos curados. Revista del Comité Científico de la AESAN(13), 59-88. 